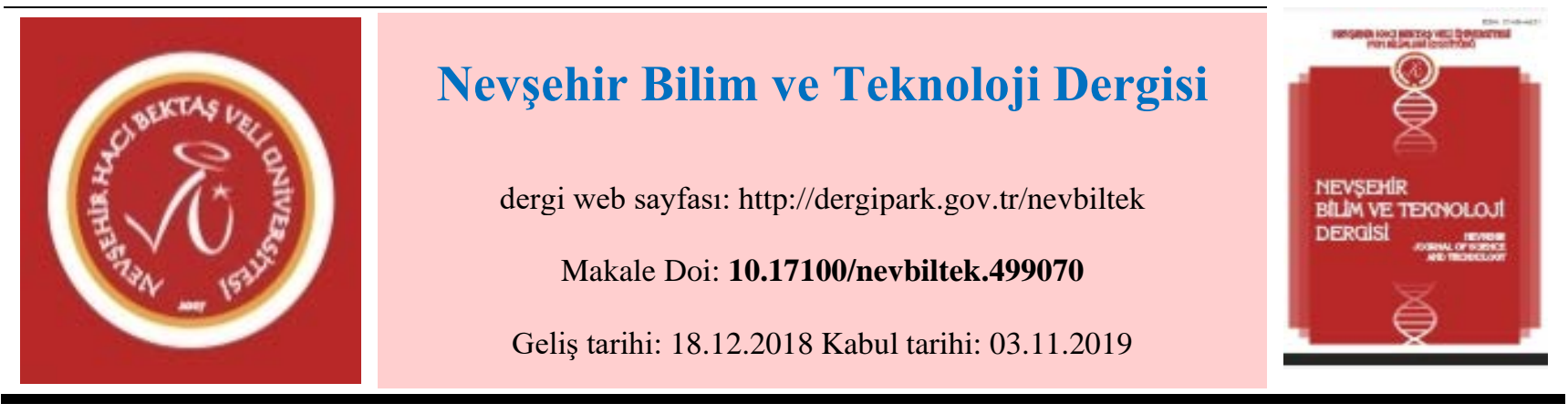

\title{
Seryum Oksit Katkılı Doğal Obsidyen Camların Mekanik Özellikleri
}

\author{
B. Aktaş ${ }^{1}$, Ş. Yalçın² A. Açıkgöz ${ }^{1}$ ve R. Şerbetci ${ }^{3}$ \\ ${ }^{1}$ Harran Üniversitesi, Mühendislik Fakültesi, Makine Mühendisliği Bölümü, Şanlıurfa \\ ORCID ID: 0000-0002-9396-1534 \\ ${ }^{2}$ Harran Üniversitesi, Fen Edebiyat Fakültesi, Fizik Bölümü, Şanlıurfa \\ ORCID ID:0000-0002-9791-5623 \\ ${ }^{3}$ Harran Üniversitesi, Fen Bilimler Enstitüsü, Şanlıurfa
}

\begin{abstract}
$\ddot{O} \mathbf{z}$
$\mathrm{Bu}$ çalışmanın amacı, ağırlıkça \%0.5-10 seryum oksit $\left(\mathrm{CeO}_{2}\right)$ obsidyen içerisine ilave edilerek yüksek mekanik özelliklere sahip doğal obsidyen camların üretilmesidir. Obsidyen cam örnekler, geleneksel ergitme metodu ile $1300{ }^{\circ} \mathrm{C}$ de 2 saat bekletilerek üretildi. Saf ve CeO $\mathrm{S}_{2}$ ilave edilmiş obsidyen cam örneklerinin yoğunlukları Arşimet prensibi ile belirlendi. Numunelerin sertlik ve kırılma toklukları, Micro-Vickers çentik testi kullanılarak ölçüldü. $\mathrm{CeO}_{2}$ ilaveli obsidyen camın $\mathrm{XRD}$ desenleri, tüm $\mathrm{CeO}_{2}$ ilaveli örneklerde silikon oksit içerdiğini gösterdi. CeO ${ }_{2}$ ilavesiyle obsidyen camın yoğunluğunda bir artış meydana geldi. Mekanik test sonuçları, $\mathrm{CeO}_{2}$ 'nin obsidyene \%1 oranına kadar ilave edilmesi sertlikte hafif bir artışa neden oldu. Ayrıca, obsidyen cam örneklerin kırılma tokluğu ise ağırlıkça \%5 $\mathrm{CeO}_{2}$ ilavesiyle 1,65’den 1,91 $\mathrm{MPa}^{0,5}$ değerine arttı̆̆ belirlendi. Sonuç olarak, obsidyen camların mekanik özelliklerinin $\mathrm{CeO}_{2}$ ilavesiyle arttırılabileceği bulundu.
\end{abstract}

Anahtar Kelimeler: Doğal obsidyen cam, Seryum oksit $\left(\mathrm{CeO}_{2}\right)$, Sertlik, Kırılma tokluğu

\section{Mechanical Properties of Natural Obsidian Glasses \\ Doped with Cerium Oxide}

\begin{abstract}
The objective of this study was to manufacture the natural obsidian glasses, which have high mechanical properties with adding of Cerium oxide at $0.5-10$ wt. $\% \mathrm{CeO}_{2}$ to obsidian glass. Obsidian glass samples were produced by conventional melting method at $1300{ }^{\circ} \mathrm{C}$ for $2 \mathrm{~h}$. The densities of pure and $\mathrm{CeO}_{2}$-added obsidian glass samples were determined by Archimedes' principle. The Hardness and fracture toughness of samples were measured using Micro-Vickers indentation tests. XRD patterns of obsidian glass added with $\mathrm{CeO}_{2}$ showed that all $\mathrm{CeO}_{2}$ added samples included silicon oxide. The density of obsidian glass increased with $\mathrm{CeO}_{2}$ addition. The mechanical test results showed that $\mathrm{CeO}_{2}$ addition up to 1 wt.\% content to the obsidian caused a slightly increase in the hardness. Further, fracture toughness of obsidian glass samples changed from 1.65 to $1.91 \mathrm{MPa} \cdot \mathrm{m}^{0.5}$ with 5 wt. $\% \mathrm{CeO}_{2}$ addition. As a result, it was found that the mechanical properties of the obsidian glasses could be enhanced through $\mathrm{CeO}_{2}$ addition.
\end{abstract}

Keywords: Natural obsidian glass, Cerium Oxide $\left(\mathrm{CeO}_{2}\right)$, Hardness, Fracture toughness 


\section{Giriş}

Obsidyen; volkanik patlamalarda yüksek silikon ve alüminyum içerikli akışkan volkanik lavların hızlı bir şekilde soğumasıyla oluşan doğal volkanik bir camdır. Obsidyen, tamamen bozuk atomik yapısından dolayı fiziksel olarak amorf ve izotropiktir. Obsidyenler benzer kimyasal özelliklerinden dolayı çoğunlukla dumanlı kuvarsla karıştırılır. Obsidyen minerale benzerdir fakat cam gibi kristal olmadığı için gerçekte ise bir mineral değildir bununla birlikte kimyasal bileşimi ise çok karmaşıktır. Obsidyen minerali kristallerden oluşmadığı için gerçek bir kaya gibi değildirler. Bazen bir mineraloid olarak sınıflandırılır. Genellikle siyah, gri, açık kahverengi renklerde olduğu gibi bantl1, çizgili ve simli halde de bulunabilir [1-6]. Coğrafi olarak, obsidyenler riyolittik patlama olmuş bölgelerde bulunur. Akdeniz, Güney Amerika'nın Andes Dağları Orta Avrupa, Türkiye, Doğu Afrika, Batı Amerika Birleşik Devletleri ve Alaska, Trans-Meksika volkanik kuşağı, Japonya, Yeni Zelanda ve Güney Pasifik adaları obsidyenin bulunabileceği en yaygın bölgelerdir [7, 8]. Çoğu obsidyen kaynağının yaşı yüz bin yıldan daha azdır. Jeolojik ömrü nispeten kısadır. Yakın çağlarda, obsidyen çeşitli uygulamalar için farklı yerlerde kullanılmıştır. Obsidyenler çeşitli araçlarda, maskelerde, silahlarda, aynalar ve takı yapımında tarih öncesi zamanlardan beri kullanılmıştır. Maya toplumunun dağlık alanlarında tüm hanelerde avlanma ve tarım gibi gündelik işler için obsidyen kullanılmıştır [9]. Bıçaklar, mızrak ve dart noktaları, prizmatik bıçaklar Maya'da kullanılan bazı obsidyen alet örnekleridir. Obsidyen ustaca işlendiğinde, yeryüzündeki en keskin aletleri yapmak için kullanılabilmektedir. Obsidyenin pratikte kullanımı oldukça yaygındır. Ayrıca, Kuzey Amerika ve Güney Amerika gibi dünyanın bazı bölgelerinde obsidyen farklı hastalıklara karşı şifa olarak kullanıldı. Gerilim ve depresyonun azaldığı ve duyguların salınmasına yardımcı olduğu düşünülüyordu [8].

Birçok araştırmacı tarafından obsidyen camların yapısı ve özellikleri ile ilgili çalışmalar yapılmıştır. Dorfman ve ark. 15 çeşit obsidyenin mekanik özelliklerini incelemiştir. Bu çalışmada obsidyenin mikro ve nano-girinti, XRD, SEM ve TEM ile mekanik ve yapısal analizi üzerinde durulmuştur. Obsidyenin mikro-mekanik özelliklerinin, kireç camı ve erimiş kuvars dahil çeşitli yapay cam türlerine karşı güçlü ayırt edici davranışlarını yitirdikleri sonucuna vardılar [10]. Husien’nin yapmış olduğu yüksek lisans tez çalışmasında 3 farklı renkteki obsidyen ve bunlara referans malzemelerin mekanik özelliklerini karşılaştırmıştır. Siyah, pembe ve kaplan gözü rengindeki obsidyen camlar ile referans materyal olarak da silikat cam ve optik cam kullanılmış ve çalışmada kullanılan tüm obsidyen camların sertliğinin silikat camlardan ve optik camlardan daha büyük olduğunu göstermiştir [11].

Literatürde yapılan birçok çalışmalar, katkılı malzemelerin, saf halinden daha iyi arzu edilen fiziksel özelliklere sahip olduğunu göstermiştir $[12,13]$. Bu nedenle, bu çalışmada; farklı oranlarda $\mathrm{CeO}_{2}$ ilavesinin doğal volkanik obsidyen camın fiziksel ve mekanik özellikleri üzerine olan etkilerini Miko-Vickers sertlik ölçme cihazı, optik mikroskop ve XRD yardımıyla araştırıldı.

\section{Materyal ve Metot \\ 2.1. Camlarn Hazerlanması}

Obsidyen cam örneklerine $\mathrm{CeO}_{2}$ ağırlıkça \%0, 0.5, 1, 5 ve 10 oranlarında ilave edilerek cam kompozisyonları hazırlandı [14-17]. Cam örneklerin üretimi geleneksel ergitme ve hızlı soğutma yöntemiyle gerçekleştirildi. Öncelikle, obsidyen kayaç parçaları agat havanda öğütülerek toz haline getirildi ve farklı kompozisyonlarda $\mathrm{CeO}_{2}$ ile birlikte öğütülmüş obsidyen tozları bir atritör içerisinde 200 rpm’de 1 saat karıştırıldı. Farklı kompozisyondaki $\mathrm{CeO}_{2}-\mathrm{Obssidyen}$ toz karışımları grafit kalıplara yerleştirildi ve ardından elektrikli fırında 2 kademeli olacak şekilde birinci olarak $900{ }^{\circ} \mathrm{C}$ 


\section{Nevşehir Bilim ve Teknoloji Dergisi (20xx), $\mathrm{x}(\mathrm{x}) \mathrm{x}-\mathrm{xx}$}

sıcaklıkta 2 saat bekletildikten sonra $1330{ }^{\circ} \mathrm{C}$ sıcaklığa çıkarılarak bu sıcaklıkta camların homojenleşmesi için 3 saat bekletme yapılarak hazırlanan cam kompozisyonlarının ergitme işlemi gerçekleştirildi. Daha sonra grafit kalıp içerisinde ergitilmiş cam örnekler fırın dışına çıkarılarak camlaşmaları sağlandı. Camlaştırılan $\mathrm{CeO}_{2}$ ilaveli obsidyen cam örnekler şekillendirilmek için grafit kare kalıplar içerisinde $1100{ }^{\circ} \mathrm{C}$ 'de presleme ile şekillendirme işlemi yapılarak $25 \times 25 \times 3 \mathrm{~mm}$ ebatlarında örnekler elde edildi. Sıcak şekillendirme aparatıyla şekillendirilen obsidyen numunelerinin termal iç gerilmelerini gidermek için $500{ }^{\circ} \mathrm{C}$ 'de 3 saat tavlama yapıldı. Elde edilen cam örnekler, ultrasonik ölçüm ve mikro sertlik ölçümleri için uygun yüzey kalitesi elde edebilmek için çeşitli zımparalama ve parlatma işlemlerine tabi tutuldu.

\subsection{XRD Analizi}

$\mathrm{CeO}_{2}$ katkılı obsidyen numunelerinde mevcut oluşabilecek fazları ve amorf camsı yapıyı görebilmek amacıyla, RigakuDmax 2000 model X ışını kırınım (XRD) cihazı kullanıldı. XRD cihazında CuK $\alpha$ radyasyonu $\left(\lambda=1.5405^{\circ} \mathrm{A}\right)$ kullanılarak 40 kV'lık bir voltaj 30 mA'lık bir anot akımı uygulanıp 2 derece/dakikada 2-90º açı aralığında kırınım desenleri belirlendi.

\subsection{Yoğunluk}

$\mathrm{CeO}_{2}$-Obsidyen cam numunelerin yoğunlukları Arşimed yöntemiyle belirlendi. $\mathrm{Bu}$ çalışmada hazırlanan numunelerin kütlesi öncelikle hava ortamında ölçüldü. Daha sonra sıvıya daldırılan numunelerin sıvı içerindeki kütleleri belirlendi. Bu işlemde daldırma sıvısı olarak saf su kullanıldı. Yoğunluk ölçme kitinde sıvıya daldırılmış olarak bulunan termometre ile numunenin daldırıldığı sıvının sıcaklığg da yoğunluğu etkileyen önemli bir parametre olmasından dolayı bu sıcaklık da yoğunluk kitine manuel olarak tanımlandı ve yoğunluk hesaplamaları ise Denklem 1 kullanılarak hesapland1.

$$
\rho=\frac{w_{a}}{w_{a}-w_{b}} \times \rho_{d w}
$$

Burada; $\rho_{\mathrm{dw}}$ saf suyun yoğunluğunu, $\mathrm{W}_{\mathrm{a}}$ numunenin havadaki kütlesini, $\mathrm{W}_{\mathrm{b}}$ numunenin saf su içerisindeki kütlesini temsil etmektedir.

\subsection{Mekanik Özellik Ölçümleri}

Kristal yapılı malzemelerde özellikle cam ve türevlerinde malzemelerin sertliği önemli bir parametre olarak karşımıza çıkmaktadır. Cam örneklerin sertlikleri Mikro-Vickers yöntemi ile farklı bölgelerden 5 adet ölçüm alınarak yapılmıştır. Ölçümlerde 5 saniye boyunca 9.81 N yük uygulandı ve sertlikler Denklem 2 kullanılarak belirlendi.

$$
H_{V}=\frac{1.854 P}{d^{2}}
$$

Burada; P uygulanan yükü, d oluşan diyagonallerin ortalama uzunluğunu temsil etmektedir. Kırılma tokluğu değerleri, sertlik testlerinde parçanın kenarlarında oluşan çatlak uzunluklarının ölçülmesiyle hesaplandı. Çatlaklar, yük ve çevresel faktörlerden etkilenmeyecek şekilde numuneye uyguladıktan hemen sonra ölçüldü. Cam örneklerin kırılma toklukları, Anstis ve arkadaşları [18] tarafından önerilen Denklem 3 kullanılarak hesaplandı. 


$$
K_{I C}=0.016\left(\frac{E}{H_{V}}\right)^{1 / 2}\left(\frac{P}{C^{3 / 2}}\right)
$$

Burada; E Young modülünü, $\mathrm{H}_{\mathrm{v}}$ Vickers'ın sertliğini, $\mathrm{P}$ uygulanan yükü, c oluşan çatlak uzunluklarının ortalamasını temsil etmektedir.

\section{Bulgular}

Saf ve ağırlıkça \%0.5, 1, 5 ve 10 oranlarında $\mathrm{CeO}_{2}$ içeren obsidyen cam örneklerin XRD desenleri Şekil 1.'de gösterilmektedir. $\mathrm{CeO}_{2}$ ilaveli obsidyen cam örneklerin XRD desenleri, tüm $\mathrm{CeO}_{2}$ ilave miktarlarında $\mathrm{SiO}_{2}$ 'in camsı fazının oluştuğunu göstermiştir. Ayrıca, camsı yapı içerisinde bazı kristal fazlarının oluştuğu gözlenmiştir. Bu fazların ise muhtemelen çeşitli oksit bileşiklerine ait olabileceği düşünülmektedir.

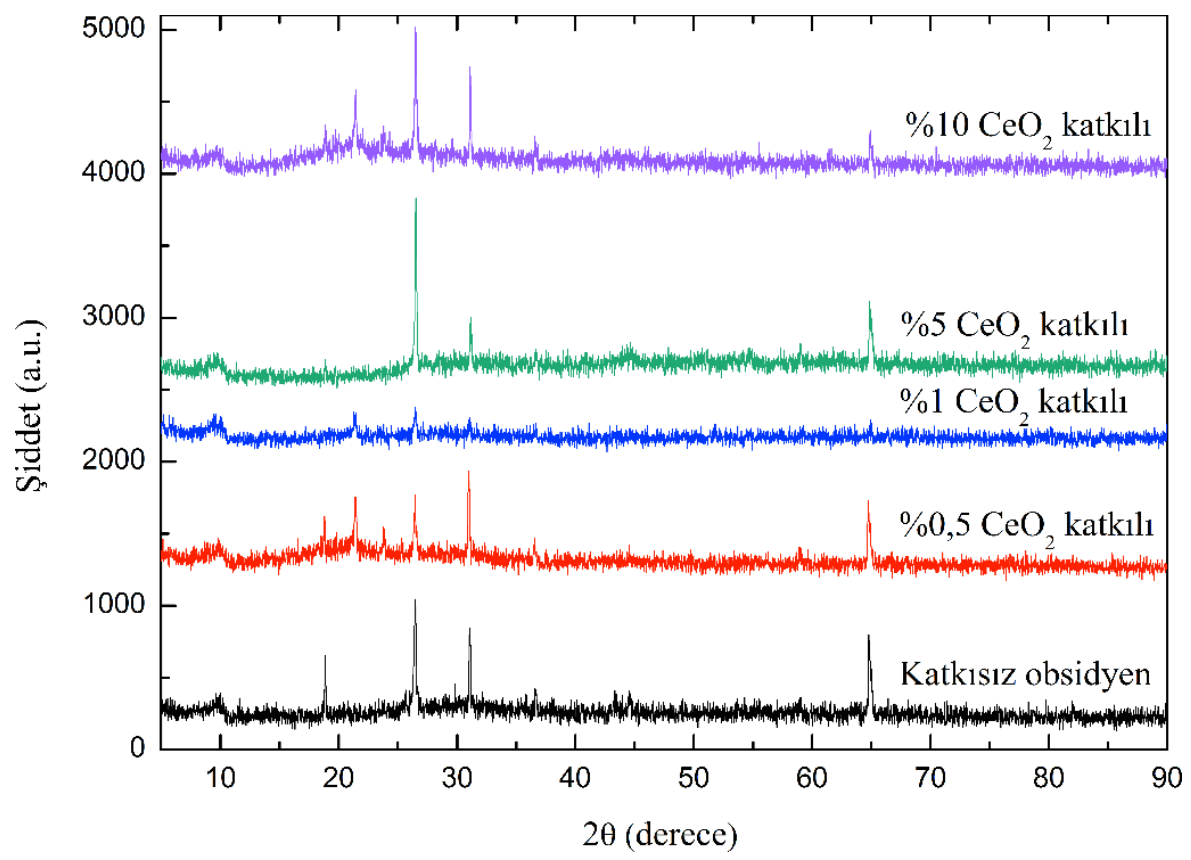

Şekil 1. $\mathrm{CeO}_{2}$ katkılı obsidyen cam örneklerin X-ışını kırınım desenleri.

Saf ve $\mathrm{CeO}_{2}$-obsidyen cam örneklerin yoğunluk sonuçları Şekil 2'de verilmektedir. $\mathrm{CeO}_{2}$ ilavesi ve katk1 miktarının artması ile birlikte obsidyen cam örneklerin yoğunluğunda bir artış olduğunu göstermektedir. Bu durum; obsidyen içerisine ilave edilen $\mathrm{CeO}_{2}$ 'in yoğunluğunun $\left(6,2 \mathrm{gr} / \mathrm{cm}^{3}\right)$ obsidyenin yoğunluğundan $\left(2,12 \mathrm{gr} / \mathrm{cm}^{3}\right)$ fazla olmasıyla açıklanabilir. Ayrıca ergitme sırasında oluşan bazı yüksek yoğunluklu fazlar da bu artışın diğer bir sebebi olabileceği düşünülmektedir. 
Nevşehir Bilim ve Teknoloji Dergisi (20xx), $\mathrm{x}(\mathrm{x}) \mathrm{x}$-xx

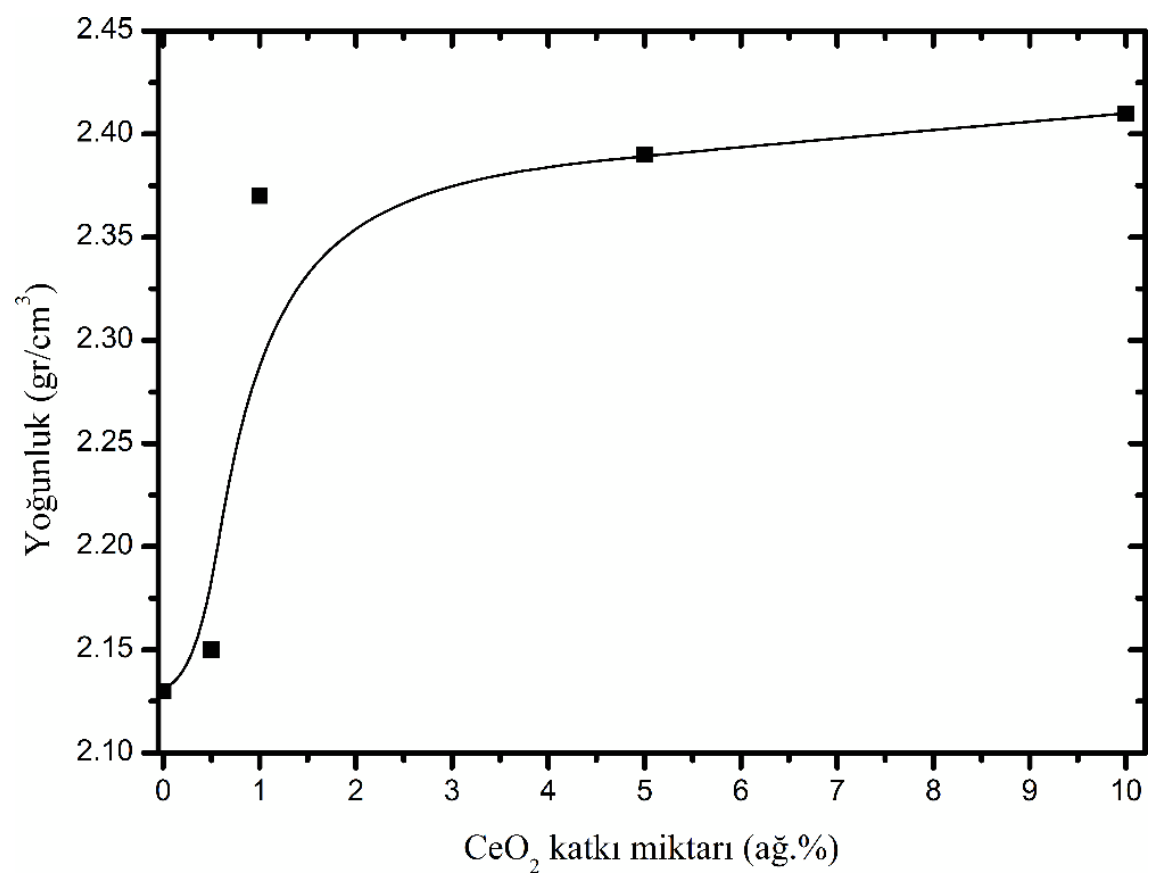

Şekil 2. $\mathrm{CeO}_{2}$ ilavesi ile obsidyen camın yoğunluğundaki değişim.

Saf ve $\mathrm{CeO}_{2}$ katk1lı obsidyen cam örneklerinin fiziksel ve mekanik özellikleri Tablo 1'de verilmektedir. Burada $\mathrm{CeO}_{2}$ katkı miktarına bağlı olarak obsidyen camın elastisite modülü artmaktadır. Obsidyenin sertliği, ağırlıkça \%1 CeO ilavesinde bir miktar arttı ve daha sonra \%1 oranından daha fazla $\mathrm{CeO}_{2}$ içeriklerinde ise sertlik değerlerinin azaldığ 1 gözlemlendi. Obsidyen camın gevreklik indeks değerleri ise $\mathrm{CeO}_{2}$ ilavesi birlikte azalmıştır. Genel olarak cam malzemelerin kırılma toklukları ile sertlik değerleri arasında sıkı bir ilişki olmakla beraber değişimleri paralellik göstermeyebilir. Obsidyen camların kırılma toklukları, ağırlıç̧a \%5 $\mathrm{CeO}_{2}$ ilavesine kadar önemli bir artış getirirken ağırlıkça \%10 $\mathrm{CeO}_{2}$ ilavesinde ise çok keskin bir azalma olduğunu gösterdi. Obsidyen camların kimyasal bileşiminin büyük çoğunluğu silika ve önemli miktarda da alüminadan oluştuğunu göstermektedir. Camın bileşimindeki bu artan alümina içeriği, camın yapısını daha sert hale getirir ve elastik özelliklerde bir artış sağlar [11].

Tablo 1. Saf ve $\mathrm{CeO}_{2}$ katkılı obsidyen cam örneklerinin fiziksel ve mekanik özellikleri.

\begin{tabular}{|c|c|c|c|c|c|}
\hline Cam kompozisyonları & $\begin{array}{c}\mathrm{E} \\
(\mathrm{GPa}) \\
\end{array}$ & $\begin{array}{c}\rho \\
\left(\mathrm{kg} / \mathrm{m}^{3}\right) \\
\end{array}$ & $\begin{array}{c}\mathrm{Hv} \\
(\mathrm{GPa}) \\
\end{array}$ & $\begin{array}{c}\text { KIC } \\
\left(\text { MPa.m }^{0.5}\right) \\
\end{array}$ & $\begin{array}{l}\text { Gevreklik } \\
\text { (B) }\left(\mu \mathrm{m}^{-0.5}\right) \\
\end{array}$ \\
\hline Saf obsidyen & 80 & 2,13 & $6,54 \pm 0.12$ & 1,65 & 3,96 \\
\hline \%0.5 $\mathrm{CeO}_{2-} \% 99,5$ obsidyen & 80,5 & 2,15 & $6,74 \pm 0.12$ & 1,74 & 3,87 \\
\hline$\% 1 \mathrm{CeO}_{2}-\% 99$ obsidyen & 81 & 2,37 & $6,68 \pm 0.21$ & 1,84 & 3,63 \\
\hline \%5 $\mathrm{CeO}_{2}-\% 95$ obsidyen & 85 & 2,39 & $6,50 \pm 0.24$ & 1,91 & 3,40 \\
\hline$\% 10 \mathrm{CeO}_{2}-\% 90$ obsidyen & 90 & 2,41 & $6,03 \pm 0.27$ & 1,49 & 4,05 \\
\hline
\end{tabular}

Saf ve $\mathrm{CeO}_{2}$ ilaveli obsidyen camların sertlik ve kırılma tokluğundaki değişim Şekil 3’de verilmektedir. Obsidyen camın sertliği, ağırlıkça \%1 $\mathrm{CeO}_{2}$ ilavesiyle artmış ve daha sonra ağırlıkça \%1 oranından sonra bir miktar azalma meydana gelmiştir. Doğal obsidyen camın kırılma tokluğu ise ağırlıkça \%0.5-5 $\mathrm{CeO}_{2}$ aralığında artmıştır. Fakat ağırlıkça \%10 oranında ise kırılma tokluğunda keskin bir şekilde azalma meydana gelmiştir. 
Nevşehir Bilim ve Teknoloji Dergisi (2019), 8(2) 165-173

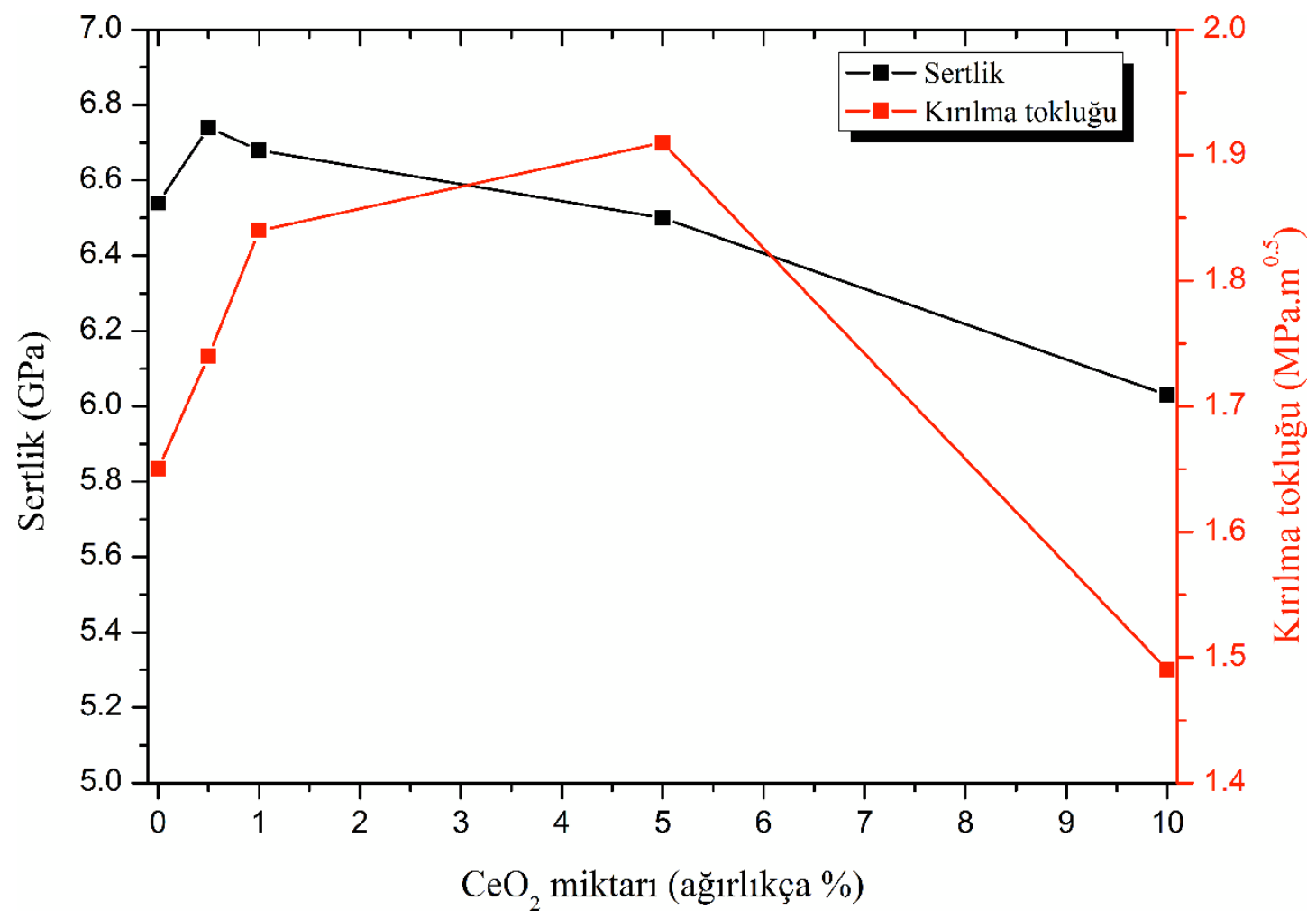

Şekil 3. $\mathrm{CeO}_{2}$ içeriğinin obsidyen camın sertliği ve kırılma tokluğuna etkileri.

Saf ve $\mathrm{CeO}_{2}$ ilaveli obsidiyen cam örneklerin Vickers çentik izleri ve kenarlarında oluşan çatlaklar Şekil 4'te verilmektedir. Tüm cam örneklere 9,8 N yük 10 sn uygulandığında, çentiğin dört köşesinde çatlaklar meydana geldi. Tüm örneklerde medyan ve radyal çatlaklar genellikle gözlendi (Şekil 4-a-e) ve ayrıca örneklerde bazı alt yüzey çatlakları ortaya çıktı̆̆ı tespit edildi. 


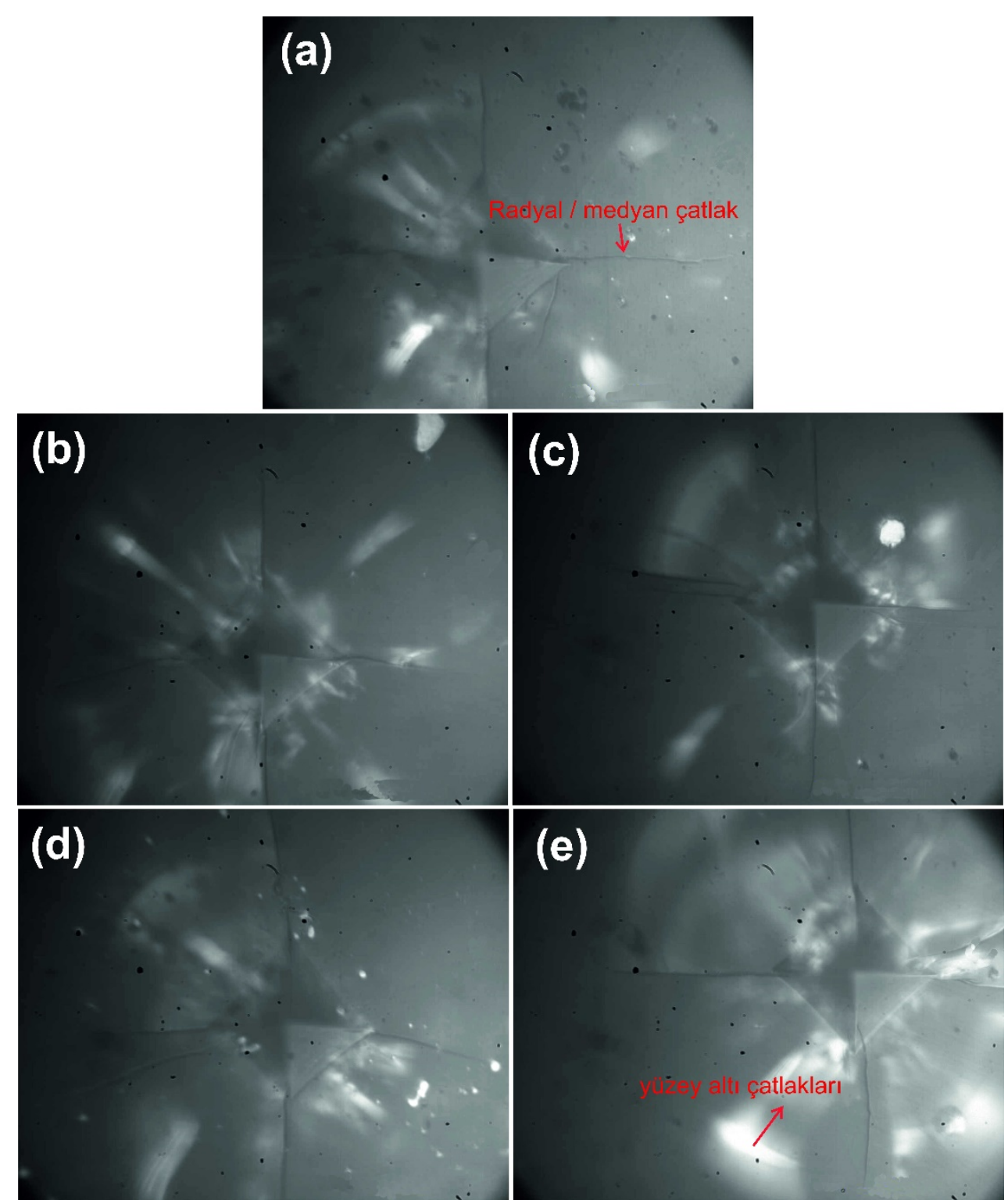

Şekil 4. Farklı çatlak uzunluklarına sahip vickers çentik izlerinin mikro fotoğrafları; (a) Saf obsidyen, (b) 0,5, (c) 1 , (d) 5 ve (e) $\% 10 \mathrm{CeO}_{2}$ ilaveli obsidyen cam

\section{Tartışma ve Sonuç}

$\mathrm{Bu}$ çalışmada; farklı oranlarda $\mathrm{CeO}_{2}$ ilaveli obsidyen camları ergitme-hızlı soğutma yöntemiyle üretilmiş ve $\mathrm{CeO}_{2}$ ilaveli obsidyen camların yapısal ve fiziksel özellikleri araştırılmıştır. Bulgulara göre; obsidyen camlara $\mathrm{CeO}_{2}$ ilavesi ile birlikte obsidyenin yoğunluğu doğru orantılı bir şekilde artmıştır. Örneklerin iç yapılarında ayrıca ergitme sırasında yapıda obsidyenden daha yüksek yoğunluklu bazı bileşiklerin oluşması, yoğunluğun artışında önemli bir etki yaptığı sonucuna varılmıştır. $\mathrm{Bu}$ çalışma sonucunda, belli oranlardaki (\%0.5, 1 ve 5) $\mathrm{CeO}_{2}$ ilave oranlarında obsidyen camın mekanik özelliklerinin arttığı tespit edilmiştir. Özellikle, $\mathrm{CeO}_{2}$ ilavesiyle obsidyen camın kırılma tokluğu ve elastisite modülü gibi mekanik özelliklerinde ciddi oranda iyileşme gözlemlenmiştir. 


\section{Kaynaklar}

[1] Morgan L.E., Renne P.R., Taylor R.E. and Gabriel G.W. "Archaeological age constraints from extrusion ages of obsidian: Examples from the Middle Awash, Ethiopia,” Quaternary Geochronology 193-203, 2009

[2] Derkowski, A. "Experimental transformation of volcanic glass from Streda nad Bodrogom (SE Slovakia)." Geologica Carpatica, 53, 2002.

[3] Negash A., Alene M., Brown F.H., Nash B.P. and Shackley M.S. "Geochemical sources for the terminal Pleistocene/early Holocene obsidian artefacts of the site of Beseka, central Ethiopia," Journal of Archaeological Science, 34, 1205-1210, 2007

[4] Smith C. S. "Obsidian use in Wyoming and the concept of curation." Plains Anthropologist, 44(169), 271-291, 1999

[5] Negash A. and Shackley M.S. "Geochemical Provenance of Obsidian Artefacts from the MSA site of Proc Epic Ethiopia,” Archaeometry, 48, 1-12, 2006

[6] Abdelounisa H.B., Elleuch K., Vargiolu R., Zahouani H. and Bot A.L. "On the behaviour of obsidian under scratch test,” Wear, 266, 621-626, 2009

[7] Bourdonnec F.L., Bontempi J.M., Marini N., Mazet S., Neuville P.F., Poupeau G. and Sicurani J. “SEM-EDS characterization of western Mediterranean obsidians and the Neolithic site of A Furta (Corsica), Journal of Archaeological Science,37, 92-106, 2010

[8] Glascock M.D., "Obsidian provenance research in the Americas." Accounts of chemical research, 35(8) 611617, 2002

[9] Nazaroff A.J., Prufer K. M., and Drake B. L., "Assessing the applicability of portable X-ray fluorescence spectrometry for obsidian provenance research in the Maya lowlands,” Journal of Archaeological Science, 37 885-895, 2010

[10] Dorfman B.F. “Obsidian-Natural Nanostructured Glass: Preliminary Research Results”, Proceedings of the XIth International Congress and Exposition, 2008 pp. 1876-1885

[11]Husien M.S. "Fracture Behavior and Mechanical Characterization of Obsidian: Naturally Occurring Glass” Master Thesis, Oklahoma State University, 2010

[12] Muz, İ., and Kurban, M., "Enhancement of electronic, photophysical and optical properties of 5,5'-Dibromo2,2'-bithiophene molecule: new aspect to molecular design”, Opto-Electronics Review, 27(2), 113-118, 2019

[13] Kurban, M., "Electronic structure, optical and structural properties of Si, Ni, B and N-doped a carbon nanotube: DFT study”, Optik, 172, 295-301, 2018

[14] Aktas, B., Albaskara, M., Dogru, K., and Yalcin, S., "Mechanical Properties of Soda-Lime-Silica Glasses Doped with Eggshell Powder”, Acta Physica Polonica A, 132(3), 436-438, 2017

[15] Aktas, B., Albaskara, M., Yalcin, S., and Dogru, K., "Mechanical Properties of Soda-Lime-Silica Glasses with Variable Peanut Shell Contents”, Acta Physica Polonica A, 131(3), 511-513, 2017

[16] Aktas, B., Albaskara, M., Yalcin, S., and Dogru, K., “Optical properties of soda-lime-silica glasses doped with peanut shell powder”, Archives of Materials Science and Engineering 82 (2), 57--61, 2016

[17] Aktas, B., Albaskara, M., Yalcin, S., and Dogru, K., “Optical Properties of Soda-lime-silica glasses doped with eggshell powder”, Acta Physica Polonica A 132 (3), 442-444, 2017 


\section{Nevşehir Bilim ve Teknoloji Dergisi (20xx), $\mathrm{x}(\mathrm{x}) \mathrm{x}-\mathrm{xx}$}

[18] Anstis, G.R., Chantikul, P., Lawn, B.R. and Marshall, D.B., “A critical evaluation of indentation techniques for measuring fracture toughness: I, direct crack measurements," Journal of the American Ceramic Society, 64(9), 533-538, 1981

\section{Extended Abstract}

\section{Introduction}

Obsidian is a natural volcanic glass formed by the rapid cooling of fluidized volcanic lava with high silicon and aluminum content in volcanic eruptions. It is similar to the obsidian mineral but it is not a mineral in reality because it is not crystal like glass, but its chemical composition is very complex. Since the obsidian mineral does not consist of crystals, they are not like a real rock. It is sometimes classified as a mineraloid. It is usually found in black, gray, light brown colors as well as banded, striped and silvery [1-6]. Geographically, obsidian is found in rhyolithic eruption regions. Mediterranean, South America's Andes Mountains, Central Europe, Turkey, East Africa, the western United States and Alaska, the Trans-Mexican volcanic belt, Japan, New Zealand and the South Pacific islands are the regions where obsidian most common [7, 8]. In the mountainous areas of the Mayan society, obsidian was used for everyday activities such as hunting and agriculture in all households [9]. Knives, spear and dart points, prismatic knives are some examples of obsidian tools used in Maya. When the obsidian is skillfully processed, it can be used to make the sharpest instruments on earth. Obsidian is widely used in practice. In addition, in some parts of the world such as North America and South America, obsidian was used as a cure for different diseases. Tension and depression were thought to be reduced and helped to release emotions [8].

Numerous studies in the literature have shown that materials containing additives has desirable physical properties rather than that of pure $[12,13]$. Therefore, in this study; The effects of different amounts of $\mathrm{CeO}_{2}$ addition on the physical and mechanical properties of natural volcanic obsidian glass were investigated by Mico-Vickers hardness tester, optical microscope, and XRD.

\section{Method}

Glass compositions were prepared by adding 0, 0.5, 1, 5 and 10 wt.\% $\mathrm{CeO}_{2}$ to obsidian glass samples [14-17]. Production of glass samples was carried out by conventional melting and rapid cooling method. First, the obsidian rock fragments were ground in an agate mortar, and pulverized, and then the different compositions of $\mathrm{CeO}_{2}$ and ground obsidian powders were mixed together in an attritor at $200 \mathrm{rpm}$ for $1 \mathrm{~h}$. $\mathrm{CeO}_{2}$-Obsidian powder mixtures of different composition were placed in graphite molds and then were first heated at $900{ }^{\circ} \mathrm{C}$ for $2 \mathrm{~h}$ in a 2-stage electric oven and then heated to $1330^{\circ} \mathrm{C}$ for $3 \mathrm{~h}$ for homogenization of the glass compositions. Afterwards, the glass samples melted in a graphite mold were taken out of the furnace to convert the glass.

RigakuDmax 2000 model X-ray diffraction (XRD) was used to determine the phases and amorphous glassy structure that may occur in obsidian samples with $\mathrm{CeO}_{2}$ doped. Densities of $\mathrm{CeO}_{2}$-Obsidian glass samples were determined by Archimedes method. The hardness of glass samples were measured by Micro-Vickers method by taking 5 measurements from different regions. Fracture toughness of glass samples was calculated using Equation 3 proposed by Anstis et al. [18].

\section{Results and Discussion}

In this study; obsidian glasses with addition $\mathrm{CeO}_{2}$ at different amounts were produced by melt-qenching method, and structural and physical properties of $\mathrm{CeO}_{2}$ added obsidian glasses were investigated. According to the findings; the density of obsidian increased in direct proportion with the addition of $\mathrm{CeO}_{2}$. It was also concluded that the formation of some compounds with higher density than obsidian in the structure during melting had an important effect on the increase of density. As a result of this study, it was found that the mechanical properties of obsidian glass increased in certain amounts $\left(0.5,1\right.$, and 5 wt.\%) of $\mathrm{CeO}_{2}$ addition. Particularly with the addition of $\mathrm{CeO}_{2}$, a significant improvement was observed in the mechanical properties of obsidian glass such as fracture toughness and modulus of elasticity. 